\title{
Human Resource Practices and Organizational Commitment Through Work Satisfaction as a Variable of Mediation
}

\author{
Retno Sari Murtiningsih* \\ Faculty of Economics and Business \\ Universitas Trisakti \\ Jakarta, Indonesia \\ *retnosari@trisakti.ac.id
}

\begin{abstract}
This study examines the impact of human resource (HR) practices on organizational commitment through job satisfaction as a mediator variable. The primary data was gathered and collected from 135 respondents being employees of some private companies in Jakarta. This study used hypothesis testing as a research design. We analyze the data by using Structural Equation Method (SEM). The results show that HR practices positively influence both organizational commitment and job satisfaction, and job satisfaction also positively influences organizational commitment.
\end{abstract}

Keywords-human resource practices, organizational commitment, job satisfaction

\section{INTRODUCTION}

Employees are valuable assets for an organization to carry out its vision, mission and in achieving organizational goals. Thus, their role is vital so that it must be appropriately managed to continue to have the motivation, job satisfaction and high commitment to the company [1]. By understanding the goals of the organization, employees are expected to implement and develop organizational strategies, so human resource must be appropriately managed to ensure that employee talents have been used effectively and efficiently to achieve organizational goals [2]. The previous research indicates that the four dimensions of human resource practices that include cooperation, communication, rewards and recognition, training and development are positively related to organizational commitment [3]. Organizational commitment shows how an employee identifies himself with an organization and the goals of the organization and desires to remain as a member of the organization [1]. Employees who are committed to an organization will have an awareness of responsibility for the development and the organization's progress. They will make a high contribution to the organization in achieving organizational goals in facing competition if they have high organizational commitment [4]. Job satisfaction is one of the essential things that we need to consider in managing human resources; in this case, the employees who work for the company. Employees who have job satisfaction tend to have a high level of attendance and performance and are more loyal to the organization [1]. Job satisfaction reflects feelings for their work, which we can see from their positive attitude towards the work they do [5].

\section{LITERATURE REVIEW}

\section{A. Human Resource Practices}

Human resource (HR) practices are the implementation of a set of activities aimed at developing employees' competencies and skills, influencing employees' attitudes and behavior by organizational values to contribute and focus on achieving organizational goals [6]. HR practices are the primary mechanism that employees use to understand corporate rules [7]. Through various HR practices and HR development activities, a company forms an agreement and goals. Every employee needs to be motivated and facilitated to be able to develop his or her talents so that he can improve organizational performance. In this case, the duties and roles of leaders are essential in managing employees as one of the company's necessary assets [8].

\section{B. Training and Development}

Training is a process to improve knowledge and skills to be able to perform specific tasks [9]. Training is designed to give learners the amount of experience and expertise needed for their current work, while development involves learning that leaves ongoing work and has a longer-term focus [10] Training is required to improve employees' knowledge and skills to do a specific and specific task. Both training and development are essential for the employees and leaders of the organization [11]. The techniques in this development aim to 
produce changes in the people involved in the organization and encourage them to work together better [12].

\section{Reward and Recognition}

A reward is a tool used by leaders to appreciate employee performance [13]. In a broad sense, it is not just a monthly salary but also includes the development that is needed by every employee [14]. A reward has the meaning of financial and non-financial benefits received by employees through work relationships with organizations [15]. Attractive remuneration and rewards increase organizational commitment $[16,17]$

\section{Organizational Communication}

Organizational communication is the process by which individuals and groups interact with each other in various ways and various places to achieve organizational goals [18]. Its functions within organizations are controlling employees' behavior, motivating employees by explaining what needs to do and how well they have done to improve performance, expressing emotional expression and meeting social needs, and providing information to individuals and groups [12].

\section{E. Teamwork}

Teamwork is increasingly essential for organizations to increase employees' productivity and organizational commitment [19]. This collaboration within an organization can increase employees' commitment to the organization [20]. It can generate positive synergy through coordinated efforts, where individual efforts will produce a level of performance that is greater than the amount of personal input [21].

\section{F. Job Satisfaction}

Job satisfaction reflects a person's feelings towards his work as seen from a positive attitude towards the work he does [5]. It describes the emotions and feelings of pleasure or displeasure that arise in a person looking at his work [22]. It also refers to an emotional response to work situation, which is determined by how well a job can successfully meet or exceed individual employee expectations, and it represents several attitudes related to work [23]. Job satisfaction is a perception of what is obtained by or exceeds what is expected [24]. Job satisfaction refers to the attitudes commonly exhibited by employees towards their work.

\section{G. Organizational Commitment}

Organizational Commitment is the degree to which an employee identifies himself with a particular organization and its goals and desires to maintain its membership in the organization. Employees' commitment shows their belief that the organization values their contribution and cares for their well-being [1]. Employees who have a high level of organizational commitment will contribute highly in achieving organizational goals in the face of competition, so the engagement of employees is an important instrument to improve organizational performance [4].

\section{H. Hypothesis Development}

There are many empirical studies on the impact of HR practices. The four dimensions of HR practices that include training and development, rewards and recognition, organizational communication, and teamwork have shown to have a positive effect on organizational commitment [3]. Other studies show that training and development enhance loyalty and strengthen corporate competitiveness [25,20]. Other research shows the positive effect of effective communication on organizational commitment [18].

H1: There is a positive influence of HR practices on organizational commitment.

A reward is one of the HR Practices that positively affect job satisfaction as evidenced by the results of the previous studies [26,27]. Furthermore, in their research they stated that reward increases job satisfaction [15]. Other researches prove that training also positively affects job satisfaction [28,29]. Training is claimed to be able to increase employees' satisfaction because it can enhance their performance by acquiring knowledge from it [30].

$\mathrm{H} 2$ : There is a positive influence of HR practices on job satisfaction.

With high job satisfaction, someone will be more committed to the organization or company where he works. The results showed that there was a positive influence of job satisfaction on organizational commitment [4,16]. Other researchers also prove that job satisfaction is a determinant of organizational commitment [31]. Furthermore, they determined that job satisfaction is an antecedent variable for organizational commitment [32,33].

H3: There is a positive influence of job satisfaction on organizational commitment.

\section{METHODS}

The research method used is hypothesis testing as a method for making decisions based on experimental data processing [34]. This study uses primary data obtained by distributing questionnaires directly to the respondents by using a nonprobably sampling method [35]. This research uses purposive/judgmental sampling technique that is sampling based on certain criteria. Respondents' criteria needed for filling out the questionnaire were respondents who had worked for more than one year. Characteristics of respondents describe the general description of respondents including gender, age, education, position and length of work. The number of respondents in this study was 135 people, fulfilling the recommended minimum number of samples which is at least five times the number of question items contained in the research questionnaire, amounting to 27 items [36]. The population was all employees of some private companies located in Jakarta. There are three variables used, namely HR Practices (training \& development, rewards \& recognition, organizational communication, and teamwork), organizational commitment and job satisfaction. 
This research is a quantitative study, and the analytical method used is Structural Equation Modeling (SEM), a multivariate statistical technique that combines aspects of multiple regression and factor analysis to estimate a series of dependency relationships simultaneously [36]. This research uses the Cronbach's Coefficient Alpha method with SPSS 22, and AMOS IBM 22 software for the reliability test [37]. Validity and reliability tests are done to test data quality, where if the Cronbach's Coefficient Alpha value is more significant than $0.60(>0.60)$, then it is declared reliable [35]. Validity test is a test that measures how much a measurement instrument can measure something that should be measured [38]. Reliability is the consistency of a measuring instrument used for repeated measurements. Internal instrument reliability testing can be done only once by analyzing the compatibility of items on the device with specific techniques [38].

This research conducts Validity and Reliability test for all variables per dimension. The training and development dimension consist of six indicators, all of which have factor loadings values which are greater than 0,55 (the average value is 0.896) (Hair's Factor Loadings for 135 respondents). As such, these indicators are valid in forming the construct dimension of training and development. Cronbach's Alpha of those six indicators is 0.950, which is higher than 0.6. Therefore, they are all reliable. The reward and recognition dimension consist of 3 indicators, all of which have factor loadings values which are greater than 0,55 (the average value is 0.954). As such, these indicators are valid in shaping the constructs dimension of rewards and recognition. Cronbach's Alpha of the three indicators is 0.949, which is higher than 0.6. Therefore, all three indicators are reliable. The organizational communication dimension consists of four indicators, all of which have factor loadings values which are higher than 0.55 (the average value is 0.939). Thus, these indicators are valid in forming the construct dimension of organizational communication. Cronbach's Alpha of the four indicators is 0.953 , which is higher than 0.6. Therefore, the four indicators are reliable. The teamwork dimension consists of four indicators, all of which have factor loadings values which are higher than 0.55 (the average value is 0.923 ). As such, these indicators are valid in forming the construct dimension of teamwork. Cronbach's Alpha of the four indicators is 0.939, which is higher than 0.6. Therefore, all four indicators are reliable. The job satisfaction variable consists of four indicators, all of which have the factor loadings values, which are higher than 0.55 (the average value is 0.944). Thus, these indicators are valid in shaping the construct of the job satisfaction variable. Cronbach's Alpha of 4 indicators is 0.957 , which is higher than 0.6. Therefore, all four indicators are reliable. The organizational commitment variable consists of six indicators, all of which have factor loadings values which are higher than 0.55 (the average value is 0.853 ). Thus, these indicators are valid in forming the construct of organizational commitment variables. Cronbach's Alpha of those indicators is 0.909 , which is higher than 0.6. Therefore, the six indicators are reliable.
The results of Goodness-of-Fits Test indicate that based on the value of RMSEA, GFI, NFI, TLI and CFI, the model is goodness-of-fit. Therefore, the next step is testing theoretical hypothesis.

\section{RESULTS AND DISCUSSION}

The result of SEM analysis indicates that HR practices have a coefficient value of 0.501 with a probability value of 0.000 which is smaller than 0.05 , so that we reject Ho or there is a positive influence of $\mathrm{HR}$ practices on organizational commitment. The higher the perception of HR practices, the higher the perception of organizational commitment. HR practices also have a coefficient value of 0.763 with a probability value of 0,000 , which is smaller than 0.05 , so that we reject Ho or there is a positive influence of HR practices on job satisfaction. The higher the perception of HR practices, the higher the perception of job satisfaction. Job satisfaction has a coefficient value of 0.268 with a probability value of 0.029 , which is smaller than 0.05 , so that we reject Ho, or there is a positive influence of job satisfaction on organizational commitment. The higher the perception of job satisfaction, the higher the perception of organizational commitment.

\section{CONCLUSION}

The four dimensions of human resource management practices in this study include training \& development, reward $\&$ recognition, organizational communication and teamwork. All are proven to have a positive influence on job satisfaction and organizational commitment. Based on this conclusion, the results of this study provide implications for HR management to continue improving the quality of those $\mathrm{HR}$ practices to increase employees' job satisfaction as well as the organizational commitment to increasing the organizational performance and productivity. The limitation of this research includes the limited number of respondents and the limited number of HR practices dimensions. For further studies, it is suggested to have more respondents and consider the impact of other aspects of HR practices on job satisfaction and organizational commitment.

\section{REFERENCES}

[1] Robbins, Stephen P.; Coulter, Mary. Management, Pearson Education, Inc., 2013.

[2] R.L. Mathis and J. H. Jackson, Human Resources Management. 13th.ed South-Western Cengage Learning. Ohio, 2011.

[3] I.A. Peter and A. E. Eunice, "The link between human resource management practices and organizational commitment," Indian J. Manag. Sci., vol. 4, no. 1, pp. 10-18, 2014.

[4] M. Noor and B. Khanam, "Relationship of work motivation and organisational commitment with job satisfaction of female police constables," J. Organ. Hum. Behav., vol. 3, no. 4, 2014.

[5] S.P. Robbins and T.A. Judge, Organizational Behavior. 17th Edition. Pearson Education, Inc. New Jersey: Upper Saddle River, 2017.

[6] F.J.S. Cesário, "Employees perceptions of the importance of human resources management practices," Res. J. Bus. Manag., vol. 9, pp. 470 479, 2015. 
[7] C.B. Scheepers and J.G. Shuping, "The effect of human resource practices on psychological contracts at an iron ore mining company in South Africa," SA J. Hum. Resour. Manag., vol. 9, no. 1, pp. 1-19, 2011.

[8] C.A. Okafor, Organizational characteristics, practices and performance in Nigeria. Nigeria: University of Benin, 2006.

[9] T.S. Suifan, "The effect of human resources practices on organizational commitment: A Jordanian study," J. Manag. Res., vol. 7, no. 4, pp. 222 232, 2015.

[10] R.W. Mondy, Human Resource Management.10th Edition. Pearson Education, New Jersey: Inc., Upper Saddle River, 2008.

[11] M. Joshi, Human Resource Management. 1st. ed. Bookboon.com., 2013.

[12] S.P. Robbins, Organization Behavior, Pearson, 2013

[13] Z. Chelangat and H. Gachunga, "Effect of Reward Management Practices on Organizational Commitment in State Corporation in Kenya: A Case Study of Kefri,” Strateg. J. Bus. Chang. Manag., vol. 3, pp. 325 346, 2016.

[14] M. Armstrong and D. Brown, Strategic Reward Making It happen United States: Thomson- Shore, Inc., 2006.

[15] K. Jehanzeb, M.F. Rasheed, and A. Rasheed, "Impact of rewards and motivation on job satisfaction in banking sector of Saudi Arabia," Int. J. Bus. Soc. Sci., vol. 3, no. 21, 2012.

[16] C. Perryer, C. Jordan, I. Firns and A. Travaglione, "Predicting turnover intentions: The interactive effects of organizational commitment, and perceived organizational support," Management Research Review, vol. 33, no. 9, pp. 911-923, 2010.

[17] J.P. Meyer and E.R. Maltin, "Employee commitment and well-being: A critical review, theoretical framework and research agenda," J. Vocat. Behav., vol. 77, no. 2, pp. 323-337, 2010.

[18] Y. Brunetto and R. Farr-Wharton, "Does the talk affect your decision to walk: A comparative pilot study examining the effect of communication practices on employee commitment post managerialism," Management Decision, 2004

[19] D. Adebanjo and D. Kehoe, "An evaluation of factors influencing teamwork and customer focus. Managing Service Quality," An International Journal, vol. 11, no. 1, pp. 49-56, 2001

[20] N. aria and Z.A. Ahmad, "Quality practices that pay: Empowerment and teamwork," Malaysian Management Review, vol. 35, no. 2, pp. 66-76, 2000 .

[21] S.P. Robbins and T.A. Judge, Organizational Behavior. 16th Edition. Pearson Education. New Jersey: Inc., Upper Saddle River, 2015.

[22] M. Rod and N.J. Ashill, "Management Commitment to service Recovery Performance: A study of frontline employees in public and private hospitals in New Zealand," International Journal of Pharmaceutical and Healthcare marketing, vol.4, no.1, 2010.

[23] F. Luthans, Organizational Behavior, 10th Edition. Mc Graw-Hill Irwin, 2005 .
[24] M.A. Griffin, M.G. Patterson, and M.A. West, "Job satisfaction and teamwork: The role of supervisor support,” J. Organ. Behav. Int. J. Ind. Occup. Organ. Psychol. Behav., vol. 22, no. 5, pp. 537-550, 2001.

[25] T. Acton and W. Golden, "Training: The way to retain valuable IT employees," in Conference Proceedings, Informing Science, vol. 10, p. 2434, 2002

[26] E. Galanou, I. Sotiropoulos, G. Georgakopoulos, and D. Vasilopoulos, "The effect of reward system on job satisfaction in an organizational chart of four hierarchical levels: a qualitative study," J. Hum. Sci., vol. 8, no. 1, pp. 484-519, 2011.

[27] M.M.N. Absar, M.T. Azim, N. Balasundaram, and S. Akhter, "Impact of human resources practices on job satisfaction: Evidence from manufacturing firms in Bangladesh," Econ. Sci. Ser., vol. 62, no. 2, pp. 31-42, 2010.

[28] H. Vasudevan, "Examining the relationship of training on job satisfaction and organizational effectiveness," Int. J. Manag. Bus. Res., vol. 4, no. 3, pp. 185-202, 2014

[29] N.S. Chaudhary and P. Bhaskar, "Training and development and job satisfaction in education sector," Train. Dev., vol. 2, no. 8, 2016.

[30] K. Jehanzeb and N.A. Bashir, "Training and development program and its benefits to employee and organization: A conceptual study," Eur. J. Bus. Manag., vol. 5, no. 2, 2013.

[31] F. Yang and C. Chang, "Emotional Labor, Job Satisfaction and Organizational Commitment Amongst clinical nurses: a questionnaire survey," International Journal Nurses Study, pp. 879-888, 2007.

[32] A. Ismail and M.R.A. Razak, "Effect of Job Satisfaction on Organizational Commitment," Management \& Marketing, vol. XIV, no. 1, pp. 26-40, 2016.

[33] N.M.D. Puspitawati and I.G. Riana, "Pengaruh Kepuasan Kerja Terhadap Turnover Intention Dengan Komitmen Organisasi Sebagai Variabel Intervening Pada PT. AutoBagus Rent Car, Bali,” E. Journal Manajemen Unud, vol. 4, no. 4, pp. 1100-1118, 2014.

[34] Y. Sun, K. Djouani, B.J. Van Wyk, Z. Wang and P. Siarry, "Hypothesis Testing- Based Adaptive PSO. Journal of Engineering," Design and Technology, vol. 12, pp. 89-101, 2014.

[35] U. Sekaran and R. Bougie, Research Methods for Business: A Skill Building Approach, 7th Edition. United Kingdom: John Wiley \& Son Ltd., 2016.

[36] J. Hair, W.C. Black, B.J. Babin and R.E. Anderson, Multivariate Data Analysis. Seventh Edition. New Jersey: Prentice-Hall, Upper Saddle River, 2010.

[37] I. Ghozali, Model Persamaan Structural Konsep Aplikasi Dengan Program AMOS 22.0. Semarang: Penerbit Universitas Diponegoro, 2011

[38] Sugiyono, Memahami Penelitian Kuantitatif. Bandung: Alfabeta, 2012. 